\title{
Intestinal Ischemia-Reperfusion Suppresses Biliary Excretion of Hepatic Organic Anion Transporting Polypeptides Substrate
}

\author{
Hajime Maruyama, Jiro Ogura, Asuka Fujikawa, Yusuke Terada, Takashi Tsujimoto, Takahiro Koizumi, Kaori \\ Kuwayama, Masaki Kobayashi, Hiroaki Yamaguchi, Ken Iseki \\ Laboratory of Clinical Pharmaceutics \& Therapeutics, Division of Pharmasciences, Faculty of Pharmaceutical Sciences, \\ Hokkaido University, Sapporo, Japan.
}

Received, July 22, 2013; Revised, October 24, 2013; Accepted, November 16, 2013; Published, November 17, 2013

\begin{abstract}
Purpose. Intestinal ischemia-reperfusion (I/R) causes gut dysfunction and promotes multi-organ failure. The liver and kidney can be affected by multi-organ failure after intestinal I/R. Organic anion transporting polypeptides (OATPs) and organic anion transporters (OATs) are recognized in a broad spectrum from endogenous compounds to xenobiotics, including clinically important drugs. Therefore, it is important for understanding the pharmacokinetics to obtain evidence of alterations in OATPs and OATs expression and transport activities. In the present study, we investigated the expression of rat Oatps and Oats after intestinal I/R. Methods. We used intestinal ischemia-reperfusion (I/R) model rats. Real-time PCR and Western blotting were used to assess mRNA and protein expression levels. Plasma concentration and biliary excretion of sulfobromophthalein (BSP), which is used as a model compound of organic anion drugs, were measured after intravenous administration in intestinal I/R rats. Results. Although Oat1 and Oat3 mRNA levels were not altered in the kidney, Oatp1a1, Oatp1b2 and Oatp2b1 mRNA levels in the liver were significantly decreased at 1-6 h after intestinal I/R. Moreover, Oatp1a1 and Oatp2b1 protein expression levels were decreased at $1 \mathrm{~h}$ after intestinal I/R. Plasma concentration of BSP, which is a typical substrate of Oatps, in intestinal $\mathrm{I} / \mathrm{R}$ rats reperfused $1 \mathrm{~h}$ was increased than that in sham-operated rats. Moreover, the area under the concentration-time curve $\left(\mathrm{AUC}_{0-90}\right)$ in intestinal $\mathrm{I} / \mathrm{R}$ rats reperfused $1 \mathrm{~h}$ was significantly increased than that in sham-operated rats. The total clearance $\left(\mathrm{CL}_{\mathrm{tot}}\right)$ and the biliary clearance $\left(\mathrm{CL}_{\text {bile }}\right)$ in intestinal I/R rats reperfused $1 \mathrm{~h}$ were significantly decreased than those in sham-operated rats. Conclusions. Oatp1a1 and Oatp2b1 expression levels are decreased by intestinal I/R. The decreases in these transporters cause alteration of pharmacokinetics of organic anion compound. The newly found influence of intestinal I/R on the expression and function of Oatps may be a key to perform appropriate drug therapy.
\end{abstract}

This article is open to POST-PUBLICATION REVIEW. Registered readers (see "For Readers") may comment by clicking on ABSTRACT on the issue's contents page.

\section{INTRODUCTION}

Intestinal ischemia-reperfusion ( $\mathrm{I} / \mathrm{R})$ induces severe intestinal mucosa injury (1). Moreover, intestinal $\mathrm{I} / \mathrm{R}$ induces remote organ failure, including the lung (2), liver (3) and kidney (4), resulting in multi-organ failure (5). Intestinal ischemia accounts for only about $1-2 \%$ of gastrointestinal illnesses but the incidence has been increasing considerably (6). The liver and kidney are major organs for detoxification of xenobiotics, including drugs. Hepatic or renal transporters contribute to the elimination of various compounds and prevent the accumulation of potentially harmful compounds in the bile or urine. Therefore, hepatic or renal transporters play a critical role in the host defense mechanism. The excretion of compounds mediated by transporters is vectorial transport from blood circulation to bile or urine. For the uptake step, organic anion transporting polypeptides (OATPs), organic anion transporters (OATs) and organic cation transporters (OCTs) have been shown to be involved in the transport of organic anions and organic cations. For the efflux step, ATP-binding cassette (ABC) transporters, including P-glycoprotein (P-gp), multidrug resistance-associated proteins (MRPs) and breast cancer resistance protein (BCRP) have been shown to be involved in the transport of various compounds.

OATPs or OATs express predominantly in the liver or kidney, respectively, and are recognized in a broad spectrum from endogenous compounds to

Corresponding Author: Ken Iseki, Ph. D., Laboratory of Clinical Pharmaceutics \& Therapeutics, Division of Pharmasciences, Faculty of Pharmaceutical Sciences, Hokkaido University Kita-12-jo, Nishi-6-chome, Kita-ku, Sapporo, Japan, E-mail: ken-i@pharm.hokudai.ac.jp 
xenobiotics, including clinically important drugs. Therefore, it is important for understanding the pharmacokinetics to obtain evidence of alterations in OATPs and OATs expressions and transport activities. Indeed, functional changes in OATPs and OATs sometimes influence the pharmacological and toxicological effects of drugs as well as their pharmacokinetics $(7,8)$.

It is known that expression levels of $\mathrm{ABC}$ transporters are altered by intestinal I/R (9-14). These alterations occur in the intestine, liver and kidney. Moreover, pharmacokinetics of several $\mathrm{ABC}$ transporter substrates are altered by intestinal $\mathrm{I} / \mathrm{R}(9,12,13,15)$. However, there has been no report on alterations in expressions and transport activities of uptake transporters, including Oatps and Oats after intestinal $I / R$. In this study, we investigated the alterations in expression levels of Oatps and Oats after intestinal I/R. We also assessed transport activities of Oatps by examining excretion into bile of sulfobromophthalein (BSP), a typical substrate of Oatps.

\section{MATERIALS AND METHODS}

\section{Chemicals}

BSP was purchased from Sigma-Aldrich Japan (Tokyo, Japan). All other reagents were of the highest grade available and used without further purification.

\section{Animals}

Male Wistar rats, aged 6 weeks, were obtained from Jla (Tokyo, Japan). The rats were housed for at least 1 week (until reaching 250-350 $\mathrm{g}$ in weight). The housing conditions were the same as those described previously (16). The experimental protocols were reviewed and approved by the Hokkaido University Animal Care Committee in accordance with the "Guide for the Care and Use of Laboratory Animals".

\section{Intestinal I/R model}

Surgical procedures were carried out as described in previous reports $(10,11,16)$. The animals were anesthetized with sodium pentobarbital $(30 \mathrm{mg} / \mathrm{kg}$ body weight, i.p. injection). Through a midline laparotomy, each rat was subjected to $30 \mathrm{~min}$ of ischemia by ligating small anastomosing vessels and occluding the superior mesenteric artery (SMA). Reperfusion was induced by removing the clamp. The abdomen was sutured during reperfusion.

\section{Assessments of biochemical parameters}

Aspartate aminotransferase (AST), alanine aminotransferase (ALT), blood urea nitrogen (BUN) or creatinine were measured by a kit (Transaminase CII-Test-Wako, L type Wako UN or L type Wako creatinine F) purchased from Wako Pure Chemical Industries (Osaka, Japan).

\section{Semi-quantitative real-time PCR}

Total RNA was prepared from organs of rats using an ISOGEN (Nippon Gene, Tokyo, Japan) and an RNase-Free DNase Set (QIAGEN, Tokyo, Japan). Single-strand cDNA was made from $2 \mu \mathrm{g}$ total RNA by reverse transcription (RT) using a ReverTra Ace (TOYOBO, Osaka, Japan). Semi-quantitative real-time PCR was performed using an ABI PRISM 7700 Sequence Detector (Applied Biosystems, Foster City, CA) with Platinum $^{\circledR}$ SYBR $^{\circledR}$ Green qPCR SuperMix-UDG (Invitrogen, Carlsbad, CA) as per the manufacturer's protocol. PCR was performed using rat Oatp1a1-specific primers, rat Oatp1a4-specific primers, rat Oatp2b1-specific primers or rat Oat3-specific primers through 40 cycles of $95{ }^{\circ} \mathrm{C}$ for $15 \mathrm{~s}, 50{ }^{\circ} \mathrm{C}$ for $30 \mathrm{~s}$ and $72{ }^{\circ} \mathrm{C}$ for $30 \mathrm{~s}$; using rat Oat1-specific primers through 40 cycles of $95{ }^{\circ} \mathrm{C}$ for $15 \mathrm{~s}, 52{ }^{\circ} \mathrm{C}$ for $30 \mathrm{~s}$ and $72{ }^{\circ} \mathrm{C}$ for $30 \mathrm{~s}$; using rat Oatp1b2-specific primers through 40 cycles of $95{ }^{\circ} \mathrm{C}$ for $15 \mathrm{~s}, 56^{\circ} \mathrm{C}$ for $30 \mathrm{~s}$ and $72{ }^{\circ} \mathrm{C}$ for $30 \mathrm{~s}$; or using rat GAPDH-specific primers all after pre-incubation at $50^{\circ} \mathrm{C}$ for $2 \mathrm{~min}$ and $95^{\circ} \mathrm{C}$ for 15 min. The primers specific to rOatp1a1, rOatp1a4, rOatp1b2, rOatp2b1, rOat1, rOat3 and rGAPDH were designed on the basis of sequences in the GenBank $^{\mathrm{TM}}$ database (accession no.: NM_017111, U95011, NM_031650, NM_080786, NM_017224, NM_031332 and AF1068 $\overline{6} 0$, respectively). The sequences of the specific primers are shown in Table 1 (17-18). The PCR products were normalized to amplified GAPDH, which was the internal reference gene (housekeeping gene). Standard curves were prepared for each target and housekeeping gene. The standard curve was established between the threshold cycles $(\mathrm{Ct})$ and the $\log _{10}$ (copy numbers) by using the Applied Biosystems sequence detection system software, version 1.9.1. The software calculates the relative amount of the target gene and the housekeeping gene based on the $\mathrm{Ct}$. 
Table 1 Primer sequences for real-time PCR

\begin{tabular}{|c|c|c|c|c|}
\hline Gene & $\begin{array}{l}\text { Gene bank } \\
\text { accession }\end{array}$ & Sequences & Product size (bp) & References \\
\hline \multirow{2}{*}{ rGAPDH } & \multirow{2}{*}{ AF106860 } & Forward 5'-ATG GGAAGC TGG TCATCAAC-3' & \multirow{2}{*}{221} & \\
\hline & & Reverse 5'-GTG GTT CACACC CAT CACAA-3' & & \\
\hline rOatp1a1 & NM_017111 & $\begin{array}{l}\text { Forward 5'-ACC TGG AAC AGC AGT ATG GAAAA-3' } \\
\text { Reverse 5'-ACC GAT AGG CAAAAT GCT AGG TAT-3' }\end{array}$ & 163 & St-Pierre et al., 2004 \\
\hline rOatp1a4 & U95011 & $\begin{array}{l}\text { Forward 5'-TGT GAT GAC CGT TGA TAA TTT TCC A-3' } \\
\text { Reverse 5'-TTC TCC ACA TAT AGT TGG TGC TGAA-3' }\end{array}$ & 81 & St-Pierre et al., 2004 \\
\hline rOatp1b2 & NM_031650 & $\begin{array}{l}\text { Forward 5'-CCT GTT CAAGTT CAT AGA GCA GCA-3' } \\
\text { Reverse 5'-TGC CAT AGT AGG TAT GGT TAT ATT TC-3' }\end{array}$ & 88 & St-Pierre et al., 2004 \\
\hline rOatp2b1 & NM_080786 & $\begin{array}{l}\text { Forward 5'-ACG ACT TTG CCC ACC ATAGC-3' } \\
\text { Reverse 5'-CCACGT AAAGGC GTA GCA TGA-3' }\end{array}$ & 117 & St-Pierre et al., 2004 \\
\hline rOat1 & NM_017224 & $\begin{array}{l}\text { Forward 5'-GTG GTT GCT CCC CTACTG CT-3' } \\
\text { Reverse 5'-ATT CGG GTT GTC CTT GCT TG-3' }\end{array}$ & 160 & Komazawa et al., 2013 \\
\hline rOat3 & NM_031332 & $\begin{array}{l}\text { Forward 5'-CAACAG CAC CAG AGA CAC CA-3' } \\
\text { Reverse 5'-GAC TGAAGG CAG CAC CAG AG-3' }\end{array}$ & 209 & Komazawa et al., 2013 \\
\hline
\end{tabular}

\section{Western blot analysis}

Lysates of liver homogenates were prepared from the livers of rats. The protein concentrations of these samples in clear supernatant were determined by the method of Lowry et al. with bovine serum albumin as a standard (19). Each sample was denatured at $100^{\circ} \mathrm{C}$ for $3 \mathrm{~min}$ in a loading buffer containing $50 \mathrm{mM}$ Tris- $\mathrm{HCl}, \quad 2 \%$ SDS, $5 \%$ 2-mercaptoethanol, $10 \%$ glycerol, $0.002 \%$ BPB and $3.6 \mathrm{M}$ urea and separated on $4.5 \%$ stacking and $10 \%$ SDS polyacrylamide gels. Proteins were transferred electrophoretically onto nitrocellulose membranes or polyvinilidene difluoride (PVDF) membranes at $15 \mathrm{~V}$ for $90 \mathrm{~min}$. The membranes were blocked with PBS containing $0.05 \%$ Tween 20 (PBS/T) and $10 \%$ or $1 \%$ non-fat dry milk for $1 \mathrm{~h}$ at room temperature. After being washed with $\mathrm{PBS} / \mathrm{T}$, the membranes were incubated overnight at room temperature with a rabbit monoclonal antibody to Oatpla1 (Millipore, Bedford, MA) (diluted 1:500), a rabbit monoclonal antibody to Oatpla4 (Santa Cruz Biotechnology, Santa Cruz, CA) (diluted 1:500), a goat monoclonal antibody to Oatp $1 \mathrm{~b} 2$ (Santa Cruz Biotechnology) (diluted 1:250), a rabbit monoclonal antibody to Oatp2b1 (Santa Cruz Biotechnology) (diluted 1:250) or a mouse monoclonal antibody to actin (Millipore) (diluted 1:500) and washed three times with PBS/T for 10 min each time. The membranes were subsequently incubated for $1 \mathrm{~h}$ at room temperature with horseradish peroxidase-conjugated goat anti-rabbit secondary antibody (Santa Cruz Biotechnology), horseradish peroxidase-conjugated donkey anti-goat secondary antibody (Santa Cruz Biotechnology) or horseradish peroxidase-conjugated goat anti-mouse secondary antibody (Santa Cruz Biotechnology) at a dilution of 1:2,000 and washed three times with PBS/T for 10 min each time. The bands were visualized by enhanced chemiluminescence according to the instructions of the manufacturer (Amersham Biosciences Corp., Piscataway, NJ). The densities of bands in each lane were determined densitometrically using Scion Image (Informer technologies, Inc, Abingdon, UK). The densities of Oatps were normalized to the band density of actin, which was the internal reference protein (housekeeping protein).

\section{Intravenous administration study}

The common bile duct of each rat was cannulated with polyethylene tubing (PE-10) to collect bile specimens. After intestinal $\mathrm{I} / \mathrm{R}$, a BSP solution $(19.2 \mathrm{mg} / \mathrm{mL})$ was injected at $19.2 \mathrm{mg} / \mathrm{kg}$ through the femoral vein. Blood samples were collected from a cervical vein at 1, 3, 15, 30, 45, 60, 75 and 90 min after injection. Plasma was obtained by centrifugation $\left(850 \times \mathrm{g}\right.$ for $15 \mathrm{~min}$ at $\left.4^{\circ} \mathrm{C}\right)$ of blood samples. Bile specimens were collected at $0-15$, $15-30,30-45,45-60,60-75$ and 75-90 min after injection. The area under the concentration-time curve $\left(\mathrm{AUC}_{0-90}\right)$ was calculated using the trapezoidal rule from the concentration-time curve. The total clearance $\left(\mathrm{CL}_{\text {tot }}\right)$ and the biliary clearance $\left(\mathrm{CL}_{\text {bile }}\right)$ of BSP were calculated as 2-compartment model equation by Origin $\mathrm{J}$ : $\mathrm{C}=\mathrm{A}^{*} \exp \left((-\alpha)^{*} \mathrm{t}\right)+\mathrm{B}^{*} \exp \left((-\beta)^{*} \mathrm{t}\right) \quad(\mathrm{C} ; \quad$ plasma concentration, $\mathrm{t}$; time after administration), $\mathrm{CL}_{\text {tot }}=\mathrm{D}^{*} \alpha^{*} \beta /\left(\mathrm{A}^{*} \beta+\mathrm{B}^{*} \alpha\right) \quad(\mathrm{D} ;$ dosage amount), $\mathrm{CL}_{\text {bile }}=\mathrm{CL}_{\text {tot }} * \mathrm{M}_{\text {bile }} / \mathrm{D}$ ( $\mathrm{M}_{\text {bile }}$; bile excretion amount $)$.

\section{Analytical procedure of BSP}

One hundred $\mu \mathrm{L}$ of plasma samples and bile specimens were alkalized by $100 \mu \mathrm{L}$ of $1 \mathrm{~N} \mathrm{NaOH}$, 
and were diluted in concentration ranging from 0 to $38.4 \mu \mathrm{g} / \mathrm{mL}$ by $1 \mathrm{~N} \mathrm{NaOH}$. The concentration of BSP was measured by absorbance at $580 \mathrm{~nm}$ using an absorption spectrometer (infinite ${ }^{\circledR}$ M200, TECAN, Yokohama, Japan).

\section{Data analysis}

Statistical significance was evaluated using unpaired Student's t-test. A value of $p<0.05$ was considered significant.

\section{RESULTS}

Effect of intestinal $I / R$ on the liver and kidney In an initial experiment, we investigated liver and kidney injuries after intestinal I/R. Plasma AST was significantly increased at 1-6 $\mathrm{h}$ and plasma ALT level was significantly increased at $1 \mathrm{~h}$ after intestinal I/R (Table 2). Although plasma creatinine level was not altered at any time after intestinal $I / R$, plasma BUN level was significantly increased at 1-6 h (Table 2). These results indicated that intestinal $\mathrm{I} / \mathrm{R}$ induced liver and kidney dysfunction.

\section{Alterations in mRNA levels of Oatps and Oats}

Next, we assessed the hepatic Oatps and the renal Oats mRNA levels in intestinal $\mathrm{I} / \mathrm{R}$ rats. Oatp1a1, Oatp1a4, Oatp1b2 and Oatp2b1 abundantly express in the rat liver. Oatp1a1, Oatp1b2 and Oatp2b1 mRNA levels in the liver were decreased at 1-6 h after intestinal $\mathrm{I} / \mathrm{R}$, but Oatpla4 was not altered at any time (Fig. 1). On the other hand, Oat1 and Oat3 abundantly express in the kidney. Oat 1 and Oat3 mRNA levels in the kidney were not altered at any time after intestinal I/R (Fig. 2).
Alterations in protein expression levels of Oatps

We investigated whether protein expression levels of Oatps correlated with mRNA levels. Oatp1a1 and Oatp2b1 protein expression levels were decreased at $1 \mathrm{~h}$ (Fig. 3A and 3D). These results were associated with mRNA levels. Although Oatp1b2 mRNA level was decreased at $1 \mathrm{~h}$, Oatp1b2 protein expression level was not altered at any time (Fig. 3C). Oatp1a4 protein expression level, as well as mRNA level, was not altered at any time (Fig. 3B).

\section{Pharmacokinetics of BSP after intravenous administration}

BSP is a typical substrate of Oatps and about $70-80 \%$ of BSP is excreted to bile. Moreover, BSP is not metabolized by CYP enzymes and its quantity is easily determined. Based on these BSP characteristics, we used BSP for assessment of the transport activities of Oatps. Plasma concentration of BSP after intravenous administration was increased in intestinal I/R rats reperfused 1 and $6 \mathrm{~h}$ compared with that in sham-operated rats (Fig. 4A and $4 \mathrm{~B}$ ). Moreover, BSP excretions to bile in intestinal $\mathrm{I} / \mathrm{R}$ rats reperfused 1 and $6 \mathrm{~h}$ were 0.85 and 0.89 -fold decreased, respectively, though there was not statistical different (Fig. 4A and 4B). The $\mathrm{AUC}_{0-90 \mathrm{~S}}$ in intestinal I/R rats reperfused 1 and $6 \mathrm{~h}$ were significantly increased after intestinal $\mathrm{I} / \mathrm{R}$ (Table 3). The $\mathrm{CL}_{\text {tot }}$ and the $\mathrm{CL}_{\text {biles }}$ in intestinal $\mathrm{I} / \mathrm{R}$ rats reperfused 1 and $6 \mathrm{~h}$ were significantly decreased after intestinal I/R (Table 3). In intestinal $\mathrm{I} / \mathrm{R}$ rats reperfused $24 \mathrm{~h}$, the pharmacokinetics of BSP was recovered (Fig. 4C and Table 3).

Table 2 Time courses of plasma hepatic injury markers and renal injury markers

\begin{tabular}{|c|c|c|c|c|c|}
\hline & & & $1 \mathrm{~h}$ & $6 \mathrm{~h}$ & $24 \mathrm{~h}$ \\
\hline \multirow{4}{*}{ Liver } & AST & Sham & $0.69 \pm 0.11$ & $0.99 \pm 0.17$ & $0.47 \pm 0.12$ \\
\hline & (units/ $\mu L$ ) & I/R & $1.6 \pm 0.19^{* *}$ & $1.6 \pm 0.32^{*}$ & $0.63 \pm 0.16$ \\
\hline & ALT & Sham & $2.8 \pm 0.15$ & $7.7 \pm 1.8$ & $3.9 \pm 0.83$ \\
\hline & (units/ $\mu L$ ) & I/R & $4.3 \pm 0.30^{* *}$ & $8.6 \pm 0.37$ & $4.5 \pm 1.1$ \\
\hline \multirow{4}{*}{ Kidney } & BUN & Sham & $9.7 \pm 3.0$ & $10 \pm 5.1$ & $18 \pm 7.3$ \\
\hline & (mg/dL) & I/R & $18 \pm 7.3^{*}$ & $23 \pm 11$ & $15 \pm 7.7$ \\
\hline & Creatinine & Sham & $3.5 \pm 0.80$ & $2.5 \pm 0.18$ & $2.9 \pm 0.24$ \\
\hline & (mg/dL) & I/R & $3.8 \pm 1.0$ & $2.7 \pm 0.69$ & $2.8 \pm 0.36$ \\
\hline
\end{tabular}

Each value represents the mean \pm S.D. of 3-7 rats (AST: Sham 3 rats at 1,6 and $24 h, l / R$ rats at 1 , 6 and $24 \mathrm{~h}$; ALT; Sham 3 rats at 1, 6 and $24 \mathrm{~h}, \mathrm{l} / \mathrm{R} 3$ rats at 1, 6 and $24 \mathrm{~h}$; BUN: Sham 6 rats at $1 \mathrm{~h}$ and $6 h$ and 5 rats at $24 h$, I/R 7 rats at $1 h, 5$ rats at $6 h$ and 6 rats at $24 h$; Creatinine: Sham 4 rats at 1,6 and $24 \mathrm{~h}, \mathrm{l} / \mathrm{R} 4$ rats at $1 \mathrm{~h}$ and 3 rats at 6 and $24 \mathrm{~h}$ ).

${ }^{*} P<0.05$ significantly different from sham, ${ }^{* *} P<0.01$. 
(A) Oatp1a1

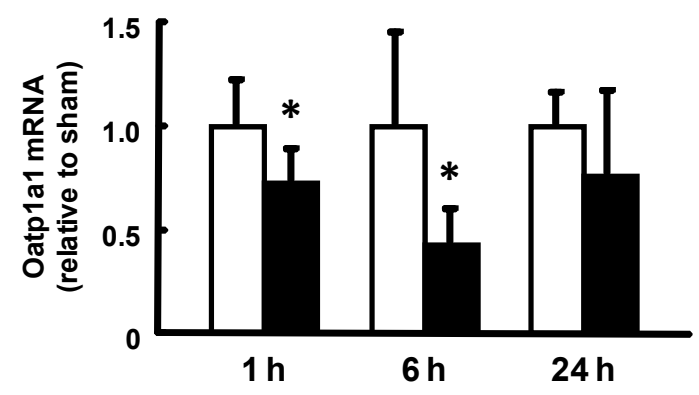

(C) Oatp1b2

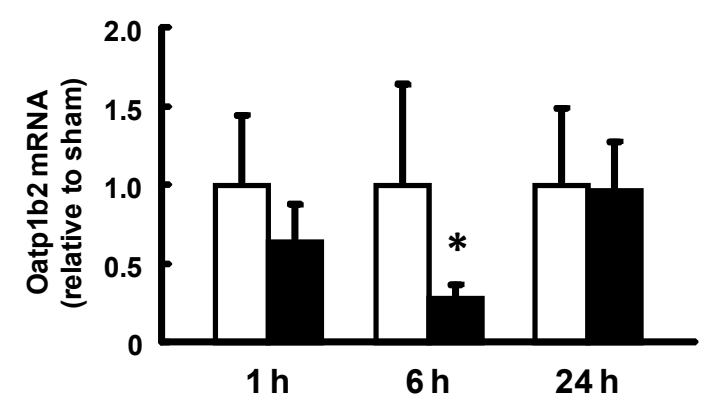

(B)Oatp1a4

Sham

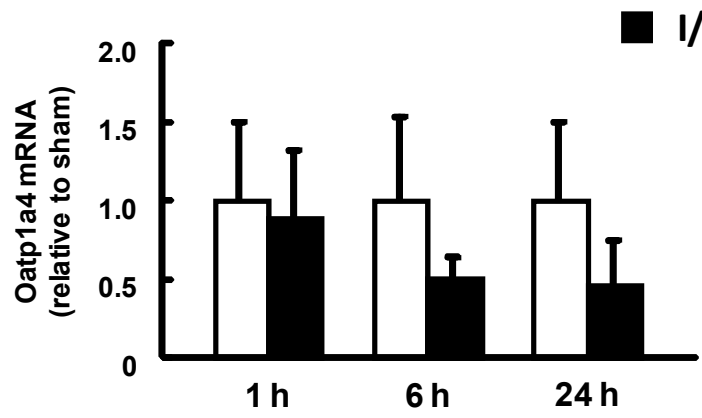

(D) Oatp2b1

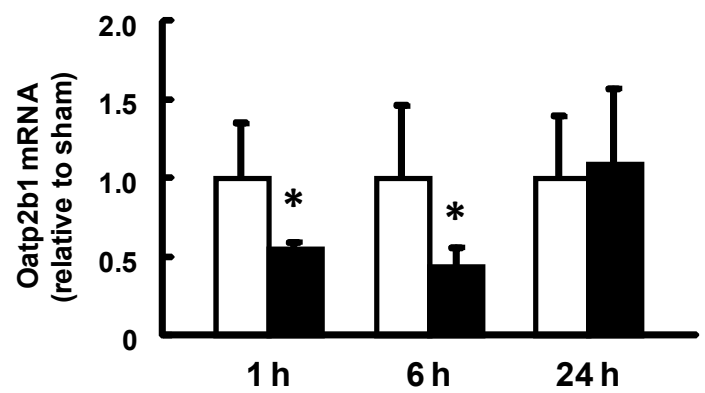

Figure 1. Time courses of the mRNA levels of Oatps in the liver after intestinal I/R. The PCR products were normalized to amplified GAPDH, which was the internal reference gene (housekeeping gene). White columns represent sham and black columns represent intestinal I/R. Each column represents the mean with S.D. of 3-6 rats (Oatp1a1: Sham 5 rats at 1, 6 and $24 \mathrm{~h}, \quad \mathrm{I} / \mathrm{R} 5$ rats at 1 and $6 \mathrm{~h}$ and 4 rats at $24 \mathrm{~h}$; Oatp1a4: Sham 5 rats at 1,6 and 24 h, I/R 4 rats at 1 h, 6 rats at 6 h and 3 rats at 24 h; Oatp1b2: Sham 5 rats at 1, 6 and $24 \mathrm{~h}, \mathrm{I} / \mathrm{R} 5$ rats at 1, 6 and $24 \mathrm{~h}$; Oatp2b1: Sham 5 rats at 1, 6 and $24 \mathrm{~h}, \mathrm{I} / \mathrm{R} 5$ rats at 1, 6 and $24 \mathrm{~h}$ ). $* P<0.05$ significantly different from sham.

(A) Oat1

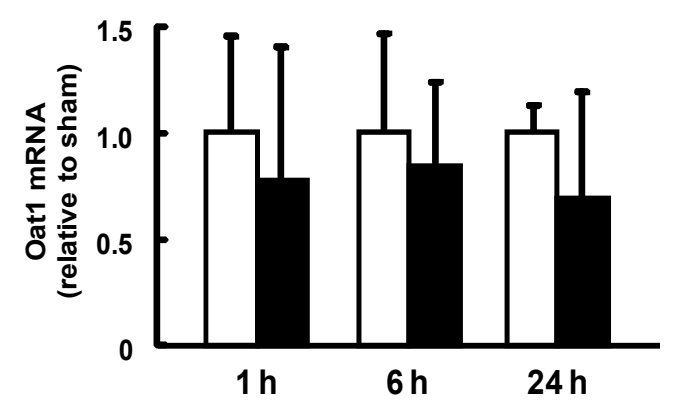

(B) Oat3

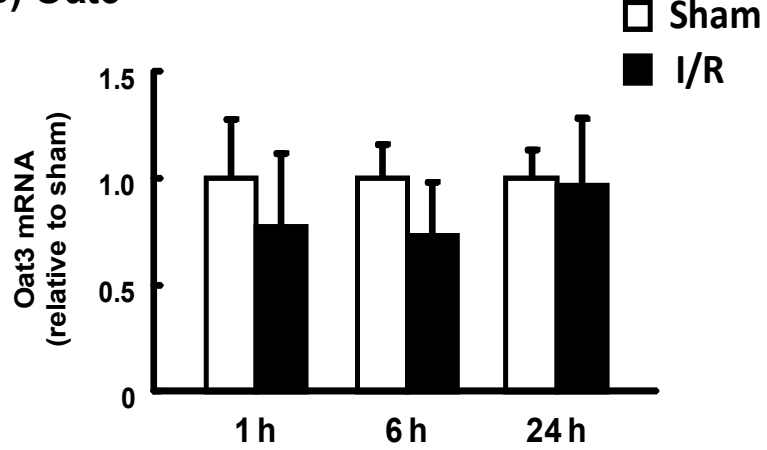

Figure 2. Time courses of the mRNA levels of Oats in the kidney after intestinal I/R. The PCR products were normalized to amplified GAPDH, which was the internal reference gene (housekeeping gene). White columns represent sham and black columns represent intestinal I/R. Each column represents the mean with S.D. of 3-5 rats (Oat1: Sham 4 rats at $1 \mathrm{~h}, 5$ rats at $6 \mathrm{~h}$ and 4 rats at $24 \mathrm{~h}, \mathrm{I} / \mathrm{R} 5$ rats at 1 and $6 \mathrm{~h}$ and 4 rats at $24 \mathrm{~h}$; Oat 3 Sham 3 rats at $1 \mathrm{~h}, 4 \mathrm{rats}$ at $6 \mathrm{~h}$ and 5 rats at $24 \mathrm{~h}, \mathrm{I} / \mathrm{R} 3$ rats at $1 \mathrm{~h}, 5$ rats at $6 \mathrm{~h}$ and 4 rats at $24 \mathrm{~h}$ ). 
(A) Oatp1a1
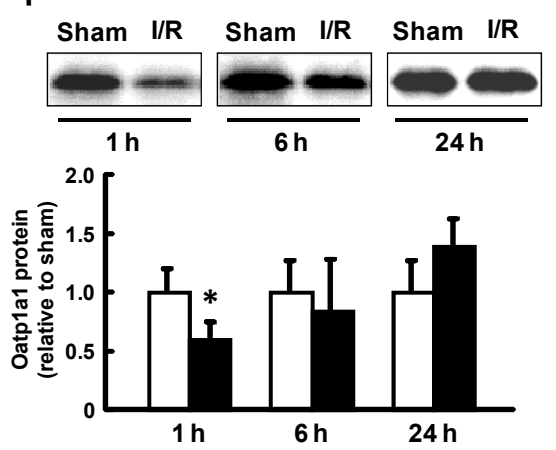

(C) Oatp1b2
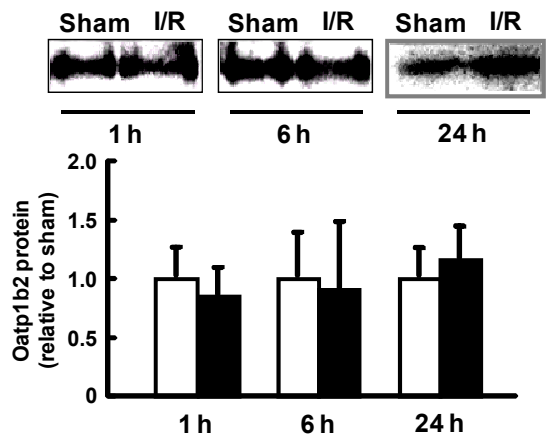

(E) Actin

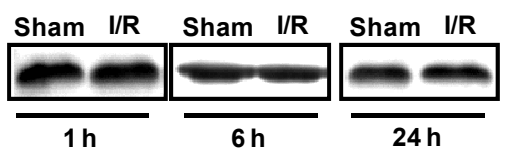

(B)Oatp1a4
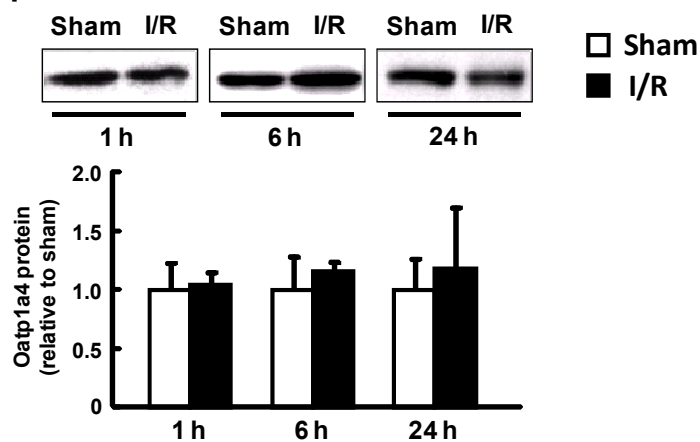

(D) Oatp2b1

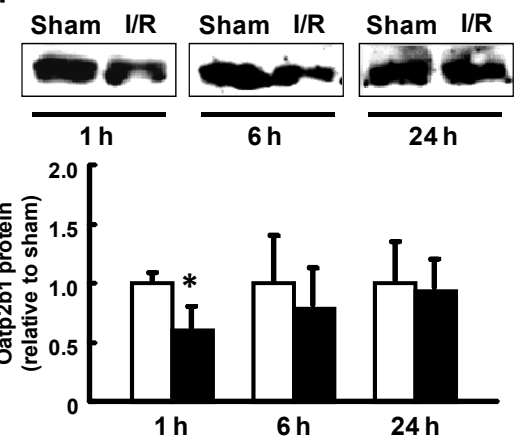

Figure 3. Time courses of the protein expression of Oatps in the liver after intestinal I/R. Whole cell lysates of rat liver at 1,6 and $24 \mathrm{~h}$ after intestinal I/R were used for Western blot analysis. Western blot band intensity was determined by densitometry using Scion image program and was normalized to band intensity of $\beta$-actin, which was the internal reference gene (housekeeping gene). White columns represent sham and black columns represent intestinal I/R. Each column represents the mean with S.D. of 3-4 rats (Oatpla1: Sham 3 rats at 1, 6 and $24 \mathrm{~h}, \mathrm{I} / \mathrm{R} 3$ rats at 1, 6 and $24 \mathrm{~h}$; Oatp1a4: Sham 3 rats at 1, 6 and 24 h, I/R 3 rats at 1, 6 and 24 h; Oatp1b2: Sham 4 rats at 1, 6 and 24 h, I/R 4 rats at 1, 6 and 24 h; Oatp2b1: Sham 3 rats at 1,6 and 24 h, I/R 3 rats at 1,6 and 24 h). ${ }^{*} P<0.05$ significantly different from sham.

Table 3 Pharmacokinetic parameters of BSP after intestinal I/R

\begin{tabular}{ccccc}
\hline & & $\begin{array}{c}\mathrm{AUC}_{0-90} \\
((\mu \mathrm{g} / \mathrm{mL}) \cdot \mathrm{min})\end{array}$ & $\begin{array}{c}\mathrm{CL}_{\text {tot }} \\
(\mathrm{mL} / \mathrm{min} / \mathrm{kg} \text { weight })\end{array}$ & $\begin{array}{c}\mathrm{CL}_{\text {bile }} \\
(\mathrm{mL} / \mathrm{min} / \mathrm{kg} \text { weight })\end{array}$ \\
\hline \multirow{2}{*}{$1 \mathrm{~h}$} & Sham & $740.3 \pm 278.5$ & $14.8 \pm 3.83$ & $10.7 \pm 3.23$ \\
& I/R & $1261 \pm 580.9^{*}$ & $9.88 \pm 3.04^{*}$ & $6.21 \pm 2.47^{*}$ \\
\multirow{2}{*}{$6 \mathrm{~h}$} & Sham & $1024 \pm 539.6$ & $11.5 \pm 4.53$ & $8.71 \pm 4.76$ \\
& I/R & $2104 \pm 427.0^{* *}$ & $5.27 \pm 1.64^{*}$ & $3.44 \pm 0.815^{*}$ \\
\multirow{2}{*}{$24 \mathrm{~h}$} & Sham & $948.7 \pm 312.7$ & $11.5 \pm 3.71$ & $8.36 \pm 3.33$ \\
& I/R & $1152 \pm 605.4$ & $10.6 \pm 5.81$ & $7.37 \pm 2.97$ \\
\hline
\end{tabular}

Each value represents the mean \pm S.D. of 4-8 measurements. ${ }^{*} \boldsymbol{P}<0.05$ significantly different from sham. 
(A) $1 \mathrm{~h}$
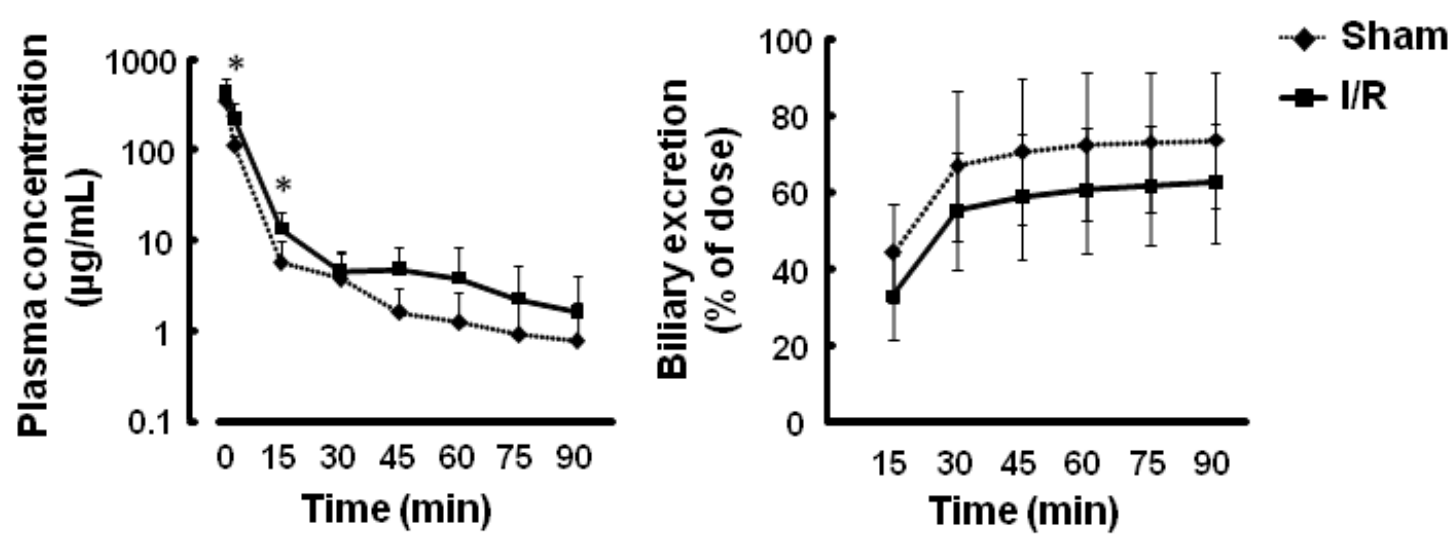

(B) $6 \mathrm{~h}$
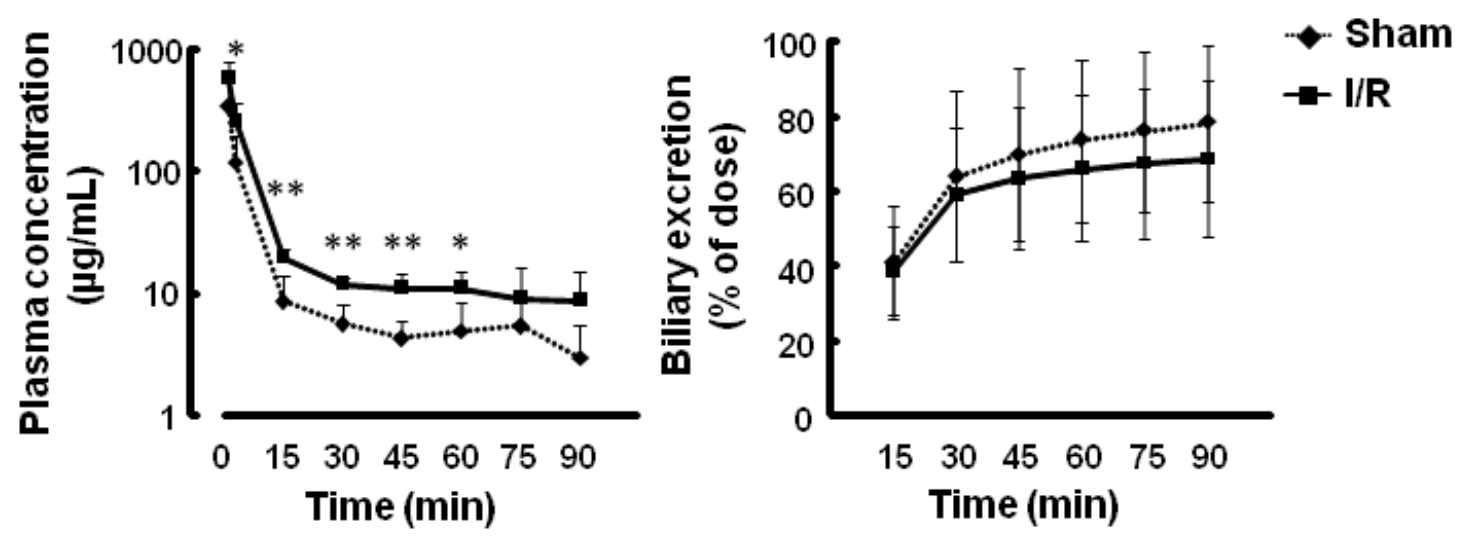

(C) $24 \mathrm{~h}$
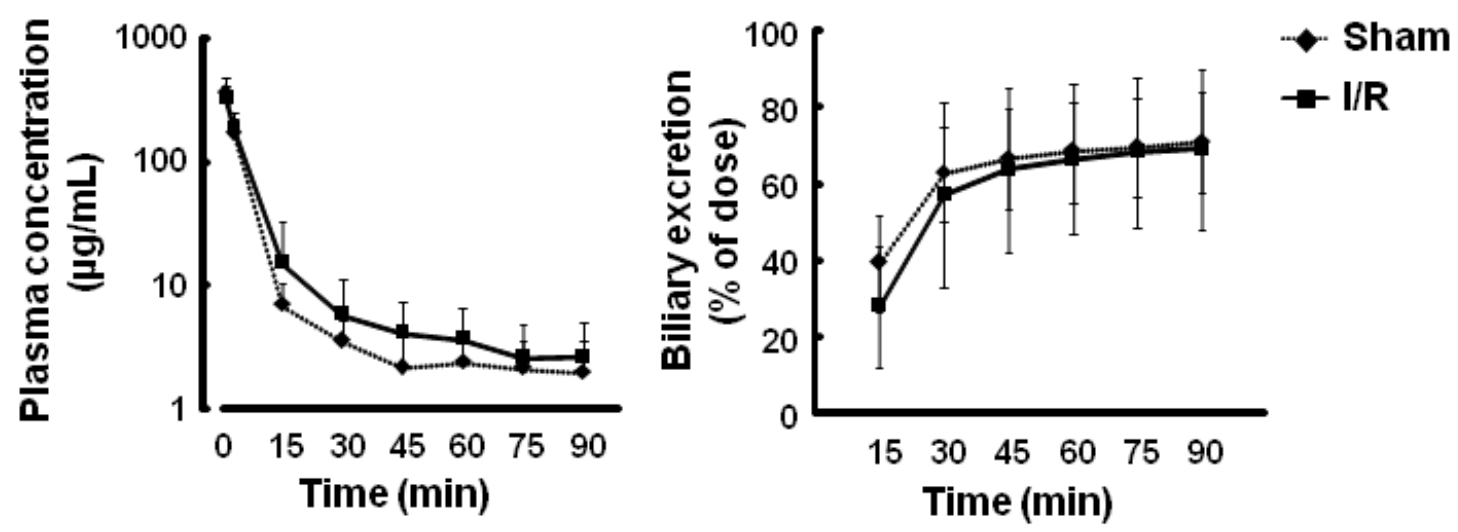

Figure 4. Time profiles of the plasma concentration and cumulative biliary excretion of intravenously administered BSP after intestinal I/R. Reperfusion times were $1 \mathrm{~h} \mathrm{(A),} 6 \mathrm{~h} \mathrm{(B)}$ and $24 \mathrm{~h}$ (C). BSP was injected at a single dose of 19.2 $\mathrm{mg} / \mathrm{kg}$ after intestinal I/R. Blood and bile samples were collected at the specified times after BSP injection. Closed diamonds represent sham and closed squares represent intestinal I/R. Each point represents the mean with S.D. of 4-8 rats (Sham 8 rats at $1 \mathrm{~h}$ and 5 rats at 6 and $24 \mathrm{~h}, \mathrm{I} / \mathrm{R} 7$ rats at $1 \mathrm{~h}, 5$ rats at $6 \mathrm{~h}$ and 4 rats at $24 \mathrm{~h}$ ). ${ }^{*} P<0.05$ significantly different from sham, $* * P<0.01$. 


\section{DISCUSSION}

The liver and kidney are major organs for detoxification of xenobiotics, including drugs. Intestinal $\mathrm{I} / \mathrm{R}$ induces severe intestinal mucosa injury. Remote organs, including the liver and kidney, are also damaged by intestinal I/R. Plasma hepatic and renal injury markers significantly increased at 1-6 $\mathrm{h}$ in our intestinal I/R model rats (Table 2). These results indicated that our intestinal $\mathrm{I} / \mathrm{R}$ model rats could be used as a model for multi-organ failure after intestinal I/R.

In clinical practice, patients usually take many kinds of drugs at the same time. Thus, changes in pharmacokinetics of drugs that have strong pharmacological effects can lead to serious adverse consequences. Pharmacokinetics of drugs may be influenced by pathophysiological conditions (20-22). Transporters can be major determinants of the pharmacokinetic, safety, and efficacy profiles of drugs (23). Oatp1a1 and Oatp2b1 protein expression levels were decreased at $1 \mathrm{~h}$ after intestinal $\mathrm{I} / \mathrm{R}$ (Fig. 3A and 3D). It has been known that intestinal $\mathrm{I} / \mathrm{R}$ induces alteration of protein expression at early stage of reperfusion, even at $1 \mathrm{~h}$ after $\mathrm{I} / \mathrm{R}(10,12)$, though changes in protein expressions need a longer time than those in mRNA levels. Oxidative stress derived from reactive oxygen species (ROS) production occurs during ischemia and early stage of reperfusion (24). Thus, the production of ROS during ischemia and early stage of reperfusion may cause the alteration of Oatp1a1 and Oatp2b1 protein expression, as well as those of mRNA. Indeed, ROS are known to decrease Oatps expression (25). Although mRNA levels of Oatp1a1, Oatp1b2 and Oatp2b1 were decreased at $6 \mathrm{~h}$ after intestinal $\mathrm{I} / \mathrm{R}$, these protein levels in intestinal $\mathrm{I} / \mathrm{R}$ rats were same as those in sham-operated rats. The decreases in Oatps expression levels by ROS were recovered with time, though mRNA levels were still decreased (25). These findings also suggested that ROS mainly caused the decreases in Oatp1a1 and Oatp2b1 expression levels after intestinal $\mathrm{I} / \mathrm{R}$. It has been also known that intestinal $\mathrm{I} / \mathrm{R}$ induces the release of inflammatory cytokines, and these are known to decrease Oatps expression. We previously reported that serum concentration of IL-6 significantly increased at 3 to $6 \mathrm{~h}$ in our intestinal I/R model rats $(11,26)$. Because Oatp1a1 and Oatp2b1 expressions were decreased at $1 \mathrm{~h}$ after intestinal $\mathrm{I} / \mathrm{R}$, IL-6 might not cause the decrease in Oatps expressions after intestinal $\mathrm{I} / \mathrm{R}$. It has been known that Oatp2b1 expresses not only in the liver but also in the intestine (27). Although Oatp2b1 mRNA level was not altered in the jejunum after intestinal $\mathrm{I} / \mathrm{R}$, Oatp2b1 mRNA level in the ileum was significantly decreased at $6 \mathrm{~h}$ after intestinal $\mathrm{I} / \mathrm{R}$ (data not shown). These results suggest that the alteration of Oatp2b1 expression in the intestine might affect the absorption of Oatp2b1 substrate drugs.

BSP is well known as anionic prototype substance and commonly used as a hepatobiliary function indicator. It has been known that Oatp1a1, Oatp1a4, Oatp1b2 and Oatp2b1 transport BSP into cells. Thus, these Oatps have influences on the uptake of BSP from blood circulation to hepatocytes. At $1 \mathrm{~h}$ after intestinal $\mathrm{I} / \mathrm{R}$, plasma concentration of BSP was higher and biliary excretion of BSP was lower than those in sham-operated rats (Fig. 4A). These results suggested that the decreases in Oatp1a1 and Oatp2b1 expression levels at $1 \mathrm{~h}$ after intestinal $\mathrm{I} / \mathrm{R}$ might cause the suppression of liver uptake of BSP, resulting in the high $\mathrm{AUC}_{0-90}$, the low $\mathrm{CL}_{\text {tot }}$ and $\mathrm{CL}_{\text {bile }}$ (Table 3). The $\mathrm{CL}_{\text {tot }}$ and $\mathrm{CL}_{\text {bile }}$ values in this study are almost consistent with the previous report in other group (28). Moreover, the difference of $\mathrm{CL}_{\text {tot }}$ between intestinal $\mathrm{I} / \mathrm{R}$ rats reperfused for $1 \mathrm{~h}$ and sham-operated rats was almost same as the difference of $\mathrm{CL}_{\mathrm{bile}}$ (Table 3), suggesting that the low $\mathrm{CL}_{\text {tot }}$ value of $\mathrm{BSP}$ in intestinal $\mathrm{I} / \mathrm{R}$ rats reperfused for $1 \mathrm{~h}$ was caused by the suppression of biliary excretion. Hepatic blood flow also affects pharmacokinetics of drugs, as well as uptake to hepatocytes by transporters. Hepatic bile flow is reduced at early stage of reperfusion (29). This finding suggested that decrease in hepatic blood flow might be another factor of the decrease in $\mathrm{CL}_{\text {tot }}$ and $\mathrm{CL}_{\text {bile }}$ of BSP. Although Oatps protein expression was recovered at $6 \mathrm{~h}$ (Fig. 3), pharmacokinetics of BSP was affected by intestinal I/R (Fig. 4B and Table 3). It has been known that MRP2/Mrp2, which expresses on the canalicular membrane, has an influence on the efflux BSP from hepatocytes to bile. In our previous study, Mrp2 expression in the liver was decreased at $6 \mathrm{~h}$ after intestinal I/R (11). Thus, the low biliary excretion of BSP in intestinal I/R rats reperfused for $6 \mathrm{~h}$ (Fig. 4B and Table 3) might be caused by the decrease in Mrp2 expression (11). When Mrp2 function is suppressed, Mrp3 excretes Mrp2 substrates from hepatocytes to blood circulation. Thus, BSP accumulated in the hepatocytes might be efflux to blood by Mrp3, resulting in the high plasma concentration of BSP in intestinal $I / R$ rats reperfused for $6 \mathrm{~h}$ (Fig. 4B and Table 3). Oatp1a1 expresses in the kidney (27), as well as in the liver, and has an influence on a renal reabsorption of 
organic anion compound (30). However, the urinary excretion of BSP was much lower $(0.3 \%$ of dose) (31) than the biliary excretion (70-80\% of dose). This finding suggests that renal Oatp1a1 has little influence on a BSP pharmacokinetics.

AST and ALT levels in sham-operated rats at 6 $\mathrm{h}$ were highest than those in sham-operated rats at the other times (Table 2). AST level in sham-operated rats at $6 \mathrm{~h}$ was significantly increased than that at $1 \mathrm{~h}$ or $24 \mathrm{~h}$ ( $\mathrm{p}$ values of both 1 $\mathrm{h}$ vs $6 \mathrm{~h}$ and $6 \mathrm{~h}$ vs $24 \mathrm{~h}$ were less lower 0.01 using one-way ANOVA followed by Tukey's test). We did not investigate the factors inducing this alteration by sham-operation, but it is possible that laparotomy may have contributed to this increment. Indeed, several workers reported that laparotomy induced the stress, and produced several stress hormones, particularly catecholamine and adrenocorticotropin (ACTH) $(32,33)$.

In conclusion, Oatp1a1 and Oatp2b1 protein expression levels are decreased by intestinal I/R. The decrease in these transporters causes high plasma concentration and low biliary excretion of organic anion compound. The newly found influence of intestinal $\mathrm{I} / \mathrm{R}$ on the expression and function of Oatps may be a key to perform appropriate drug therapy.

\section{REFERENCES}

1. Sun Z, Wang X, Deng X, Lasson A, Wallén R, Hallberg E, Andersson R. The influence of intestinal ischemia and reperfusion on bidirectional intestinal barrier permeability, cellular membrane integrity, proteinase inhibitors, and cell death in rats. Shock, 1998; 10:203-12.

2. Schmeling DJ, Caty MG, Oldham KT, Guice KS, Hinshaw DB. Evidence for neutrophil-related acute lung injury after intestinal ischemia-reperfusion. Surgery, 1989; 106:195-202.

3. Horie Y, Ishii H. Liver dysfunction elicited by gut ischemia-reperfusion. Pathophysiology, 2001; 8:11-20.

4. Mutlu G, Abbasoglu L, Dogru-Abbasoglu S, Solakoglu S, Bulut M. Morphologic changes and lipid peroxidation in renal tissues of young rats following intestinal ischemia-reperfusion. Pediatr Surg Int, 2002; 18:337-340.

5. Zhi-Yong S, Dong YL, Wang XH. Bacterial translocation and multiple system organ failure in bowel ischemia and reperfusion. J Trauma, 1992; 32:148-153.

6. Yasuhara H. Acute mesenteric ischemia: the challenge of gastroenterology. Surg Today, 2005; 35:185-195.

7. Zaher H, Meyer ZU, Schwabedissen HE, Tirona RG, Cox ML, Obert LA, Agrawal N, Palandra J, Stock
JL, Kim RB, Ware JA. Targeted disruption of murine organic anion-transporting polypeptide $1 \mathrm{~b} 2$ (Oatp1b2/Slco1b2) significantly alters disposition of prototypical drug substrates pravastatin and rifampin. Mol Pharmacol, 2008; 74:320-329.

8. Takeda M, Noshiro R, Onozato ML, Tojo A, Hasannejad H, Huang XL, Narikawa S, Endou H. Evidence for a role of human organic anion transporters in the muscular side effects of HMG-CoA reductase inhibitors. Eur J Pharmacol, 2004; 483:133-138.

9. Omae T, Goto M, Shimomura M, Masuda S, Ito K, Okuda M, Inui K. Transient up-regulation of P-glycoprotein reduces tacrolimus absorption after ischemia-reperfusion injury in rat ileum. Biochem Pharmacol, 2005; 69:561-568.

10. Ogura J, Kobayashi M, Itagaki S, Hirano T, Iseki K. Post-transcriptional regulation of breast cancer resistance protein after intestinal ischemia-reperfusion. Biol Pharm Bull, 2008; 31:1032-1035.

11. Ogura J, Kobayashi M, Itagaki S, Hirano T, Iseki K. Alteration of Mrp2 and P-gp expression, including expression in remote organs, after intestinal ischemia-reperfusion. Life Sci, 2008; 82:1242-1248.

12. Tomita M, Takizawa Y, Kishimoto H, Hayashi M. Assessment of ileal epithelial P-glycoprotein dysfunction induced by ischemia/reperfusion using in vivo animal model. Drug Metab Pharmacokinet, 2008; 23:356-363.

13. Tomita M, Kishimoto H, Takizawa Y, Hayashi M. Effects of intestinal ischemia/reperfusion on P-glycoprotein mediated biliary and renal excretion of rhodamine123 in rat. Drug Metab Pharmacokinet, 2009; 24:428-437.

14. Ogura J, Fujikawa A, Maruyama H, Kobayashi M, Itagaki S, Hirano T, Iseki K. Alteration of P-gp expression after intestinal ischemia-reperfusion following 16-h fasting in rats. Yakugaku Zasshi, 2011; 131:453-462.

15. Ogura J, Maruyama H, Kobayashi M, Itagaki S, Hirano T, Iseki K. Pharmacokinetics of oral and intravenous administration of digoxin after intestinal ischemia-reperfusion. Biol Pharm Bull, 2010; 33:922-925.

16. Ogura J, Kuwayama K, Takaya A, Terada Y, Tsujimoto T, Koizumi T, Maruyama H, Fujikawa A, Takahashi N, Kobayashi M, Itagaki S, Hirano T, Yamaguchi $\mathrm{H}$, Iseki $\mathrm{K}$. Intestinal ischemia-reperfusion increases efflux for uric acid via paracellular route in the intestine, but decreases that via transcellular route mediated by BCRP. J Pharm Pharm Sci, 2012; 15:295-304.

17. St-Pierre MV, Stallmach T, Freimoser Grundschober A, Dufour JF, Serrano MA, Marin JJ, Sugiyama Y, Meier PJ. Temporal expression profiles of organic anion transport proteins in placenta and fetal liver of the rat. Am J Physiol Regul Integr Comp Physiol, 2004; 287:R1505-R1516.

18. Komazawa H, Yamaguchi H, Hidaka K, Ogura J, 
Kobayashi M, Iseki K. Renal uptake of substrates for organic anion transporters Oat1 and Oat3 and organic cation transporters Oct1 and Oct2 is altered in rats with adenine-induced chronic renal failure. $\mathrm{J}$ Pharm Sci, 2013; 102:1086-1094.

19. Lowry OH, Rosebrough NJ, Farr AL, Randall RJ. Protein measurement with the Folin phenol reagent. J Biol Chem, 1951; 193:265-275.

20. Vos TA, Ros JE, Havinga R, Moshage H, Kuipers F, Jansen PL, Müller M. Regulation of hepatic transport systems involved in bile secretion during liver regeneration in rats. Hepatology, 1999; 29:1833-1839.

21. Enomoto A, Takeda M, Tojo A, Sekine T, Cha SH, Khamdang S, Takayama F, Aoyama I, Nakamura S, Endou H, Niwa T. Role of organic anion transporters in the tubular transport of indoxyl sulfate and the induction of its nephrotoxicity. J Am Soc Nephrol, 2002; 13:1711-1720.

22. Nowicki MT, Aleksunes LM, Sawant SP, Dnyanmote AV, Mehendale HM, Manautou JE. Renal and hepatic transporter expression in type 2 diabetic rats. Drug Metab Lett, 2008; 2:11-17.

23. International Transporter Consortium, Giacomini KM, Huang SM, Tweedie DJ, Benet LZ, Brouwer KL, Chu X, Dahlin A, Evers R, Fischer V, Hillgren KM, Hoffmaster KA, Ishikawa T, Keppler D, Kim RB, Lee CA, Niemi M, Polli JW, Sugiyama Y, Swaan PW, Ware JA, Wright SH, Yee SW, Zamek-Gliszczynski MJ, Zhang L. Membrane transporters in drug development. Nat Rev Drug Discov, 2010; 9:215-236.

24. Cizova H, Papezikova I, Kubala L, Lojek A, Ciz M. Increased antioxidant capacity of serum did not prevent lipid peroxidation in the intermittent ischemia-reperfusion of rat small intestine. Dig Dis Sci, 2006; 51:657-661.

25. Tsujimoto T, Ogura J, Kuwayama K, Koizumi T, Sasaki S, Terada Y, Kobayashi M, Yamaguchi H, Iseki K. Effect of oxidative stress on expression and function of human and rat organic anion transporting polypeptides in the liver. Int $\mathrm{J}$ Pharm, DOI; 10.1016/j.ijpharm.2013; 458:262-271.
26. Ogura J, Terada Y, Tsujimoto T, Koizumi T, Kuwayama K, Maruyama H, Fujikawa A, Takaya A, Kobayashi M, Itagaki S, Takahashi N, Hirano T, Yamaguchi H, Iseki K. The decrease in farnesoid X receptor, pregnane $\mathrm{X}$ receptor and constitutive androstane receptor in the liver after intestinal ischemia-reperfusion. J Pharm Pharm Sci, 2012; 15:616-631.

27. Shitara Y, Maeda K, Ikejiri K, Yoshida K, Horie T, Sugiyama Y. Clinical significance of organic anion transporting polypeptides (OATPs) in drug disposition: their roles in hepatic clearance and intestinal absorption. Biopharm Drug Dispos, 2013; 34:45-78.

28. Oh JH, Park SE, Shim CK, Lee YJ. Biliary clearance of bromosulfophthalein in anesthetized and freely moving conscious rat. Biopharm Drug Dispos, 2009; 30:94-98.

29. Turnage RH, Kadesky KM, Myers SI, Guice KS, Oldham KT. Hepatic hypoperfusion after intestinal reperfusion. Surgery, 1996; 119:151-160.

30. Yang $\mathrm{CH}$, Glover KP, Han X. Organic anion transporting polypeptide (Oatp) 1a1-mediated perfluorooctanoate transport and evidence for a renal reabsorption mechanism of Oatpla1 in renal elimination of perfluorocarboxylates in rats. Toxicol Lett, 2009; 190:163-171.

31. Kato Y, Kuge K, Kusuhara H, Meier PJ, Sugiyama Y. Gender difference in the urinary excretion of organic anions in rats. J Pharmacol Exp Ther, 2002; 302:483-489.

32. Muzii L, Marana R, Marana E, Paielli FV, Meo F, Maussier ML, Sciarra M, Mancuso S. Evaluation of stress-related hormones after surgery by laparoscopy or laparotomy. J Am Assoc Gynecol Laparosc, 1996; 3:229-234.

33. Geier A, Dietrich CG, Trauner M, Gartung C. Extrahepatic cholestasis downregulates Oatp1 by TNF-alpha signalling without affecting Oatp2 and Oatp4 expression and sodium-independent bile salt uptake in rat liver. Liver Int, 2007; 27:1056-1065. 